\title{
PENGEMBANGAN PEMBELAJARAN ILMU PENGETAHUAAN SOSIAL PADA PENDIDIKAN DASAR
}

\author{
Aniek Rahmaniah \\ Dosen Fakultas Tarbiyah UIN Maulana Malik Ibrahim Malang
}

\begin{abstract}
Social sciences at the school level is basically aimed to prepare students as citizens who master knowledge, skills, attitudes and values, that can be used as an ability to make decisions and participate in various community activities in order to become good citizens. To achieve these objectives, this paper discusses the development of teaching social studies in elementary education, which consists of: 1) recognize the concepts associated with society and the environment, 2) have the basic ability to think logically and critically, curiosity, inquiry, problem solving, and social skills in life, and 3) a commitment and awareness of social values and humanity, 4) have the ability to communicate, cooperate and competation in a pluralistic society, locally, nationally and globally.
\end{abstract}

Keywords: Education, Social Science

\section{A. Pendahuluan}

Ilmu Pengetahuan Sosial (IPS) sebagai mata pelajaran dalam dunia pendidikan dasar dan menengah, secara historis muncul bersamaan dengan diberlakukannya kurikulum tahun 1975. IPS memiliki kekhasan dibandingkan dengan mata pelajaran lain sebagai pendidikan disiplin ilmu, yakni kajian yang bersifat terpadu (integrated), interdisipliner, multidimensional bahkan cross-diciplinary (Numan Somantri, 2001: 101). Karakteristik ini terlihat dari perkembangan IPS sebagai mata pelajaran di sekolah yang cakupan materinya semakin meluas. Dinamika cakupan semacam itu dapat dipahami mengingat semakin kompleks dan rumitnya permasalahan sosial yang memerlukan kajian secara terintegrasi dari berbagai disiplin IPS, ilmu pengetahuan alam, teknologi, humaniora, lingkungan, bahkan sistem kepercayaan. Dengan demikian diharapkan pendidikan IPS terhindar dari sifat ketinggalan zaman, disamping keberadaannya yang diharapkan tetap koheren dengan perkembangan sosial yang terjadi.

IPS merupakan studi terintegrasi dari ilmu sosial untuk mengembangkan potensi kewarganegaraan yang dikoordinasikan dalam program sekolah sebagai pembahasan sistematis yang dibangun dalam beberapa disiplin ilmu, seperti antropologi, arkeologi, ekonomi, geografi, sejarah, hukum, filsafat, politik, psikologi, agama, sosiologi, humaniora dan ilmu-ilmu alam. Sementara itu, dalam kurikulum 
2006, mata pelajaran IPS disebutkan sebagai salah satu mata pelajaran yang diberikan mulai dari SD/MI sampai SMP/MTs. Mata pelajaran ini mengkaji seperangkat peristiwa, fakta, konsep, dan generalisasi yang berkaitan dengan isu sosial. Pada jenjang SD/MI, mata pelajaran IPS memuat materi geografi, sejarah, sosiologi, dan ekonomi. Melalui mata pelajaran IPS, peserta didik disiapkan dan diarahkan agar mampu menjadi warga negara Indonesia yang demokratis dan bertanggung jawab serta warga dunia yang cinta damai.

Sejalan dengan pengertian umum tersebut, IPS sebagai mata pelajaran di tingkat SD/MI pada hakikatnya merupakan suatu integrasi utuh dari disiplin ilmu sosial dan disiplin ilmu lain yang relevan untuk merealisasikan tujuan pendidikan di tingkat sekolah. Implikasinya, berbagai tradisi dalam IPS termasuk konsep, struktur, cara kerja ilmuwan sosial, aspek metode, maupun aspek nilai yang dikembangkan dalam ilmu sosial dikemas secara psikologis, pedagogis, dan sosial budaya untuk kepentingan pendidikan.

Tujuan pembelajaran IPS (Pusat Kurikulum, 2006: 7), adalah mengembangkan potensi peserta didik agar peka terhadap masalah sosial yang terjadi di masyarakat, memiliki sikap mental positif terhadap perbaikan segala ketimpangan yang terjadi, dan terampil mengatasi setiap masalah yang terjadi sehari-hari baik yang menimpa dirinya sendiri maupun yang menimpa masyarakat.

Berkaitan dengan tujuan IPS, Martorella (1994: 7) menyatakan bahwa:

The Social Studies are selected information and modes of investigation from the social sciences, selected information from any area that relates directly to an undestanding of individuals, groups, and societies and applications of the selected information to citizenship education.

Ilmu Pengetahuan Sosial merupakan informasi terpilih dan cara-cara investigasi dari ilmu sosial, informasi dipilih dari berbagai tempat yang berhubungan langsung terhadap pemahaman individu, kelompok dan masyarakat dan penerapan dari informasi yang dipilih untuk maksud mendidik warga negara yang baik. Dari pengertian tersebut dapat dipahami bahwa mata pelajaran IPS di SD/MI bertujuan untuk membentuk warga negara yang baik, yaitu warga negara yang memiliki kemampuan dan keterampilan yang berguna bagi diri dalam hidup sehari-hari dan warga negara yang bangga sebagai bangsa Indonesia dan cinta tanah air. (M. Hidayati: 2008). 
Menurut Fraenkel (1980: 8-11), ada empat kategori tujuan IPS, yaitu pengetahuan, keterampilan, sikap, dan nilai. Pengetahuan diartikan sebagai kemahiran dan pemahaman terhadap sejumlah informasi dan ide-ide. Tujuan pengetahuan ini adalah membantu siswa untuk belajar lebih banyak tentang dirinya, fisiknya, dan dunia sosial. Keterampilan diartikan sebagai pengembangan berbagai kemampuan tertentu untuk mempergunakan pengetahuan yang diperolehnya. Ada beberapa keterampilan dalam IPS, yaitu keterampilan berpikir, keterampilan akademik, keterampilan penelitian, dan keterampilan sosial. Sementara sikap diartikan sebagai kemahiran dalam mengembangkan dan menerima keyakinan-keyakinan, ketertarikan, pandangan, dan kecenderungan tertentu. Nilai diartikan sebagai kemahiran memegang sejumlah komitmen yang mendalam, mendukung ketika sesuatu dianggap penting dengan tindakan yang tepat.

\section{B. Pengembangan Pembelajaran IPS di SD/MI}

Berdasarkan paparan di atas, IPS di tingkat sekolah pada dasarnya bertujuan untuk mempersiapkan para peserta didik sebagai warga negara yang menguasai pengetahuan (knowledge), keterampilan (skills), sikap dan nilai (attitudes and values) yang dapat digunakan sebagai kemampuan mengambil keputusan dan berpartisipasi dalam berbagai kegiatan kemasyarakatan agar menjadi warga negara yang baik. Berdasarkan Permendiknas No. 22 Tahun 2006, orientasi utama pelaksanaan pendidikan IPS di SD/MI adalah sebagai berikut (Depdiknas, 2006):

1. Mengenal konsep-konsep yang berkaitan dengan kehidupan masyarakat dan lingkungannya.

Berikut ini langkah-langkah yang perlu diperhatikan dalam mengenalkan konsep-konsep yang berkaitan dengan kehidupan masyarakat dan lingkungannya:

a. Mengubah Konsep ke Bentuk Pemikiran yang Tepat untuk Anak Sekolah Dasar.

Konsep-konsep dan topik-topik IPS dapat dipelajari dengan berbagai tingkat kompleksitas. Berikut ini langkah-langkah yang perlu diperhatikan: 
1) Menentukan konsep dan ide-ide kunci dalam suatu bentuk yang berorientasi pada anak. Contoh konsep dan maknanya bagi anakanak:

\begin{tabular}{|l|l|}
\hline \multicolumn{1}{|c|}{ Konsep } & \multicolumn{1}{|c|}{ Maknanya Bagi Anak-anak } \\
\hline Keadilan & Bermain jujur \\
\hline Hukum & Aturan \\
\hline Kesetaraan & $\begin{array}{l}\text { Kesempatan melihat bahwa setiap orang } \\
\text { mendapat giliran }\end{array}$ \\
\hline Bertanggungjawab & $\begin{array}{l}\text { Bekerja dengan orang lain bertanggungjawab } \\
\text { melakukan tanggung jawab pihak anda atau } \\
\text { melakukan tugas anda }\end{array}$ \\
\hline
\end{tabular}

2) Memilih mata pelajaran yang bisa diidentifikasi oleh anak-anak. Ini tidak berarti bahwa topik yang dipilih untuk belajar dalam semua kasus harus dekat secara fisik dengan anak. Asumsi umum adalah bahwa hal-hal yang secara fisik dekat dengan anak akan lebih akrab daripada yang jauh. Hal ini tidak selalu terjadi, anak-anak bisa belajar tentang hal-hal jauh sehingga secara psikologis dekat dengan mereka, di sisi lain, hal-hal yang secara fisik dekat mungkin secara psikologis jauh. Gaya hidup keluarga yang tinggal di kota, misalnya, merupakan hal yang asing bagi seorang anak, dan dianggap sama seperti orang-orang yang tinggal di belahan dunia lain.

3) Mengembangkan gagasan hanya ke titik di mana anak-anak bisa menerapkannya pada realitas. Butuh waktu bagi anak-anak untuk belajar konsep, anak-anak memahami suatu gagasan secara kumulatif selama beberapa tahun.

4) Memfokuskan pada pendekatan diagnostik untuk mengajar, mencari informasi mengenai berapa banyak anak yang sudah mengetahui tentang suatu konsep. Hal ini biasanya dapat dilakukan melalui diskusi kelas informal di mana anak-anak menjawab pertanyaan-pertanyaan terbuka dari guru yang telah dipersiapkan sebelumnya. Amati seberapa baik anak-anak menggunakan istilah dan konsep baru secara alami dan mudah. Sadarilah tingkat kepentingan dari hal yang sedang dipelajari dan lukiskan pengalaman anak-anak dalam perencanaan dan pengajaran IPS. 
Doronglah anak untuk berbicara tentang materi yang dipelajari, yang berhubungan dengan kehidupan mereka.

\section{b. Strategi Membangun Konsep}

Agar memiliki makna, konsep harus dikaitkan dengan pengalaman individu, pengalaman tersebut dapat langsung dialami siswa atau orang lain, nyata atau disimulasikan. Akan tetapi, dengan cara yang berbeda tersebut, ide-ide baru harus dikaitkan dengan pengalaman sebelumnya. Konsep yang tidak dapat dikaitkan dengan pengalaman hidup tampaknya tidak relevan dengan peserta didik. Untuk alasan ini, menjadi tidak bermanfaat ketika mencoba mengajarkan IPS yang kompleks kepada anak-anak yang miskin pengalaman hidup. Inilah sebabnya mengapa benda nyata, model, ilustrasi, foto, perjalanan lapangan, film, dan contoh nyata sangat penting untuk konsep pembelajaran. Strategi pengajaran yang digunakan dalam mengembangkan konsep-konsep IPS sering dikaitkan dengan tiga cara belajar konsep berikut ini (Supriya, 2009):

1) Mendaftar, Mengelompokkan, Melabelkan

Bayangkan sebuah kelas yang baru saja kembali dari perjalanan ke supermarket dan kembali di dalam kelas, guru meminta anak-anak untuk membuat daftar sebanyak mungkin hal yang bisa mereka ingat dan pernah dilihat di supermarket. Ketika anak-anak sedang menamai benda-benda yang mereka ingat, guru menulis di papan tulis, misalnya telur, roti, kacang-kacangan, daging, mentega, kasir, petugas saham, semangka, permen, manajer toko, makanan anjing, es krim, dan sebagainya. Setelah menyelesaikan proses pencatatan tentang semua benda yang dilihat, guru meminta anak-anak untuk memeriksa daftar dan melihat apakah hal-hal tertentu dalam daftar itu termasuk dalam kategori yang sama. Artinya, barang-barang ini diletakkan bersama-sama dalam kelompok-kelompok yang memiliki sesuatu yang sama, seperti misalnya, susu, mentega, keju, krim, dan yogurt. Siswa menangkap kegiatan ini dengan cepat, dan segera menyarankan item yang dapat ditempatkan dalam kelompok yang sama, anak-anak tersebut kemudian diminta untuk memikirkan 
nama atau label untuk kelompok-kelompok. Pada contoh di atas, nama untuk grup tersebut mungkin produk-produk yang dihasilkan perusahaan susu. Strategi ini dapat digunakan dalam berbagai cara untuk mengajarkan konsep-konsep dalam IPS. Berikut adalah beberapa contoh tambahan:

a) Pengunjung asing menghabiskan hari di sekolah kita, apa yang akan dia lihat?

b) Berapa banyak daftar yang dapat Anda buat dari barang-barang yang diproduksi kota atau negara kami?

c) Barang-barang apa saja yang dijual di supermarket?

Strategi ini sangat berguna, khususnya ketika peserta didik telah melakukan sejumlah pengamatan dalam waktu singkat dan perlu memilah-milah apa yang dialami menjadi kategori yang bermakna. Ketika menggunakan strategi ini, guru dapat meminta anak menemukan contoh konsep yang terdapat dalam gambar di korankoran. Selain itu, jika guru memiliki koleksi gambar majalah yang mengilustrasikan contoh konsep, hal itu bisa digunakan dan selanjutnya meminta anak-anak mengelompokkannya.

2) Mengalami, Membuat Hipotesis, Menguji

Di negara barat, siswa SD kelas empat telah mempelajari konsep periklanan. Guru memulai pelajaran dengan meminta anak-anak untuk mencari contoh berbagai iklan yang bisa ditemukan. Pencarian ini mengungkapkan surat kabar dan iklan majalah, iklan baris, iklan radio dan televisi, billboard, tanda-tanda pada ruang transit bis, tanda-tanda di gedung-gedung publik, dan lain-lain. Berbagai metode periklanan dibahas sesuai tujuannya, penontonnya, tingkatannya (lokal, atau nasional), dan tampilan naturalnya. Hal ini bisa mendorong kelas untuk berspekulasi tentang nilai iklan. Apakah manfaat dari periklanan, dan bagaimana kegunaannya? Melalui diskusi ini, anak-anak mengembangkan hipotesis berikut:

a) Periklanan membantu konsumen karena memberitahu mereka tentang produk baru dan harganya. 
b) Iklan yang efektif ingin mencoba menciptakan produk, apakah konsumen membutuhkannya atau tidak.

c) Iklan lokal memiliki efek yang langsung terhadap penjualan di tokotoko lokal daripada iklan nasional.

Pengumpulan informasi bisa dilakukan di luar sekolah dengan mewawancarai konsumen, pedagang lokal, dan perwakilan dari biro iklan. Proses ini memaksa mereka untuk mengeksplorasi lebih jauh sub konsep seperti terkait sebagai kebutuhan dan keinginan, promosi, pendengar, klien, account, pasar, tata letak, dampak, tema, dan daya tarik penjualan. Dalam waktu singkat, mereka mampu membentuk beberapa kesimpulan sementara yang berkaitan dengan hipotesis mereka. Seluruh proses memberikan anak-anak keakraban dengan konsep iklan dari perspektif yang berbeda. Dalam bentuk lainnya, prosedur yang baru saja dijelaskan biasanya digunakan dalam pengajaran konsep-konsep IPS, dan yang terjadi adalah:

a) Pelajar disediakan pengalaman eksplorasi yang pertama, langsung, dan luas.

b) Persyaratan dan sub konsep yang berhubungan dengan konsep utama dijelaskan, dan artinya dikembangkan sebagai perpanjangan alami penelitian.

c) Anak-anak mendiskusikan ide-ide yang berhubungan dengan konsep utama dan didorong untuk berspekulasi tentang penjelasan dan hubungan yang dirasakan.

d) Pencarian informasi dibuat untuk menguji hipotesis.

e) Menarik kesimpulan sementara, yang menimbulkan hipotesis lain, dan keberlanjutan pencarian.

f) Melalui perpanjangan studi dan pengalaman langsung, arti dari konsep utama menjadi lebih luas dan disempurnakan.

Strategi ini sangat berguna untuk mengajarkan konsep-konsep seperti kebudayaan, keadilan, konflik, demokrasi, kesetaraan, dan konsepkonsep lain dalam IPS yang relatif sulit untuk didefinisikan. Pada kenyataannya, bahkan tidak ada konsensus di antara para ahli tentang makna yang tepat dari konsep-konsep ini. Konsep dipahami sebagai 
subjek untuk memperluas berbagai pengaturan selama jangka waktu yang panjang.

3) Mengenali Contoh dan Bukan Contoh

Dalam Standar Isi IPS SD/MI, dituliskan bahwa kompetensi dasar untuk kelas enam adalah membandingkan kenampakan alam dan keadaan sosial negara-negara tetangga. Guru ingin mengembangkan konsep modernisasi dan melakukannya dengan cara menulis di papan tulis halhal berikut ini, modernisasi melibatkan:

a) Penerapan teknologi untuk mengontrol sumber daya alam.

b) Penggunaan kekuatan sumber daya yang berupa benda mati dan energi.

c) Penggunaan alat-alat untuk melipatgandakan pengaruh energi yang dikeluarkan manusia.

d) Sebuah output produksi per kapita yang tinggi.

Guru kemudian menjelaskan arti masing-masing dari empat atribut dengan menggunakan gambar besar dan menunjukkan contoh di kelas. Situasi modernisasi di mana teknologi diterapkan ke kontrol sumber daya, listrik dan sumber energi, alat melipatgandakan energi manusia, dan produksi per kapita yang tinggi. Anak-anak memunculkan pertanyaan kemudian membahas dan menjelaskan masalahnya. Guru kemudian memberikan serangkaian gambar modernisasi, sebagaimana didefinisikan oleh atribut tertentu yang kurang jelas. Guru menjelaskan dan membahasnya lagi, kemudian menjawab pertanyaan yang diajukan oleh anak-anak. Setelah guru merasa puas dengan pemahaman anakanak mengenai atribut yang menunjukkan modernisasi, guru menyajikan satu set gambar. Akan tetapi, kali ini anak-anak harus mengidentifikasi contoh dan bukan contoh modernisasi, kemudian menceritakannya. Foto-foto ini dibahas secara rinci, guru kemudian memberikan isu-isu yang terkait dengan modernisasi yang berasal dari buku lain yang relevan, dan meminta anak-anak untuk menemukan contoh dan bukan contoh dari gambar modernisasi, kemudian menceritakannya. Akhirnya, guru mengevaluasi kemampuan anak-anak untuk memahami konsep ini dengan meminta mereka mengidentifikasi 
contoh dan bukan contoh dari gambar yang baru. Strategi ini akan mengurangi pertanyaan yang berorientasi penyelidikan bila dibandingkan dengan dua strategi lainnya, akan tetapi lebih menghadirkan peluang untuk mencari dan menemukan. Dalam hal ini, guru memberikan atribut konsep tersebut di awal kegiatan pembelajaran, dan bukan ditentukan sendiri oleh siswa dalam proses belajar. Hal-hal berikut ini yang perlu diperhatikan oleh guru:

a) Mengidentifikasi label konsep (modernisasi).

b) Menyediakan atribut utama (atau sifat kritis) konsep.

c) Memberikan contoh yang menggambarkan kehadiran atribut.

d) Menyediakan sesuatu yang bukan contoh terkait dengan atribut yang hilang.

e) Menyajikan contoh dan bukan contoh, dan meminta anak-anak mengidentifikasi atribut dan mereka tahu sebabnya atau mengapa tidak semua dianggap sebagai contoh.

f) Berdasarkan penggunaan konsep tersebut, anak-anak mampu menemukan sendiri contoh dan bukan contoh.

g) Mengevaluasi kemampuan dalam menggunakan atribut untuk mengidentifikasi contoh dan bukan contoh.

Banyak konsep IPS yang dapat dikembangkan dengan cara ini, strategi ini sangat berguna untuk memahami konsep, di mana ada kesepakatan masuk akal di antara para ahli pada atribut yang mendefinisikan konsep ini. Beberapa contoh lain yang bisa menggunakan strategi ini adalah pulau, daerah metropolitan, daerah industri, pasar, dan sebagainya.

2. Memiliki kemampuan dasar untuk berpikir logis dan kritis, rasa ingin tahu, inkuiri, memecahkan masalah, dan ketrampilan dalam kehidupan sosial.

Pengembangan keterampilan yang sistematis dan sekuensial sangat penting bagi anak-anak, karena keterampilan adalah alat yang akan terus mereka gunakan untuk belajar. Konsekuensinya, ketidakcukupan pengembangan keterampilan cenderung menghambat pembelajaran di banyak bidang kurikulum sekolah dasar, terutama dalam IPS. Untuk mewujudkan prestasi IPS yang memadai, dalam banyak kasus dapat ditelusuri dari 
kemampuan membaca yang kurang berkembang, ketidakmampuan untuk memahami kosakata IPS, ketidakmampuan untuk membaca peta dan bola dunia, kurangnya kemampuan belajar sambil bekerja, ketidakmampuan untuk menggunakan bahan referensi, atau keterbelakangan keterampilan bahasa.

Oleh karena itu, diperlukan instruksi yang sistematis dan terencana untuk memastikan pengembangan keterampilan ini. Keterampilan menyiratkan kemampuan melakukan sesuatu dengan baik, seseorang yang memiliki keahlian biasanya mampu merespon sesuatu dengan cara yang efisien. Keterampilan umumnya diklasifikasikan menjadi 3: yaitu motorik, intelektual, dan sosial, semua keterampilan memiliki dua karakteristik yang sama, berhubungan dengan perkembangan dan membutuhkan latihan.

Pengembangan keterampilan berarti bahwa siswa belajar secara bertahap selama bertahun-tahun, seseorang bisa terus mengasah keterampilan sepanjang hidupnya, jadi guru tidak boleh berasumsi bahwa keterampilan diajarkan dan dipelajari hanya sekali dalam beberapa kelas tertentu. Semua guru harus menganggap bahwa mereka bertanggung jawab untuk pengajaran dan pemeliharaan keterampilan IPS. Tidak ada penjelasan atau pengajaran bermakna yang membuat anak-anak menguasai keterampilan, mereka harus berlatih dan menggunakan keterampilan yang telah mereka pelajari dan diharapkan siswa berlatih keterampilan dengan tujuan untuk meningkatkan kemampuannya. Ketika pembelajaran tentang suatu topik sedang berlangsung, ada banyak kesempatan untuk mempraktekkan keterampilan dalam aktivitas pembelajaran sehari-hari di kelas. Dengan cara ini, siswa dapat meningkatkan keterampilannya ketika sedang mengembangkan pemahaman tentang konsep dan subyek.

Keterampilan yang dipelajari lebih efektif ketika langsung dikaitkan dengan situasi aktual di mana keterampilan itu digunakan. Prosedur dalam keterampilan mengajar disajikan cukup jelas, siswa pertama-tama harus memahami apa yang terlibat dalam keterampilan, bagaimana digunakan, dan apa artinya. Salah satu hal yang sangat membantu adalah memberikan model penggunaannya dengan baik. Kedua, siswa harus belajar menggunakan keterampilan dengan sederhana dan hati-hati di bawah bimbingan guru. Hal ini penting untuk memastikan bahwa mereka memahami apa yang terlibat dan 
membuat respon yang benar. Ketiga, mereka perlu latihan tambahan dalam variasi keahlian yang semakin kompleks yang diterapkan dalam pengaturan fungsional. Anak-anak perlu menggunakan keterampilan yang baru dipelajari dalam memecahkan masalah, sehingga menunjukkan nilai sebagai alat belajar. Akhirnya, mereka harus terus berlatih dalam penggunaannya selama jangka waktu yang tak terbatas untuk mempertahankan dan meningkatkan fasilitas dengan keterampilan. Guru yang membantu anak-anak mengembangkan keterampilan tidak bergantung sepenuhnya pada pengajaran yang terkait dari mereka. Sebaliknya, keterampilan diajarkan secara sistematis, diidentifikasi dengan hati-hati, dipraktekkan dengan teliti, dan digunakan. Prinsip ini berlaku untuk keterampilan intelektual seperti pemikiran kritis dan reflektif, menuju pada kesimpulan yang valid berdasarkan bukti, mengevaluasi sumber informasi, dan menafsirkan data dengan bekerja, belajar dan keterampilan proses.

Contoh langkah-langkah mengajarkan dan menerapkan keterampilan untuk menggunakan petunjuk sebuah koran. Langkah-langkah dalam mengajarkan keterampilan sebagai berikut (Jarolimek, 1967: 34 dalam Indrawati, 2009):

a. Langkah 1 Memastikan bahwa anak-anak memahami semua hal yang terlibat dalam melaksanakan keterampilan. Tunjukkan kepada mereka bagaimana menggunakannya, dan sediakan model yang baik dalam pengoperasian keterampilan.

b. Langkah 2 Membagi keterampilan ke dalam beberapa komponen dan atur mereka secara berurutan. Mengembangkan urutan mengajar langkah demi langkah, meminta anak-anak melakukan masing-masing komponen seperti yang disajikan dan dijelaskan. Mengawasi secara hati-hati untuk memastikan respon mereka sudah benar.

c. Langkah 3 Meminta anak-anak melakukan variasi keterampilan sederhana di bawah pengawasan guru, hal ini untuk memastikan bahwa mereka melakukan keterampilan dengan benar.

d. Langkah 4 Setelah anak-anak melakukan keterampilan dengan benar, masih dalam pengawasan guru, berikan latihan dan kesempatan untuk menggunakan variasi sederhana yang memastikan keberhasilan. 
e. Langkah 5 Secara bertahap meningkatkan kompleksitas variasi keterampilan, dan mulai meminta anak-anak menerapkan keterampilan dalam situasi yang sangat berguna, lanjutkan prosedur ini sampai tingkat kemampuan yang diinginkan tercapai.

f. Langkah 6 Lanjutkan untuk mempraktekkan keterampilan secara berkala, terutama melalui aplikasi fungsional, dalam rangka mempertahankan dan meningkatkan kinerja.

\section{Memiliki komitmen dan kesadaran terhadap nilai-nilai sosial dan kemanusiaan.}

Hal yang paling sering diingat ketika seorang anak beranjak dewasa adalah pengalaman dari sekolah dasar mereka mengenai cerita drama tertentu dan nilai-nilai yang terkandung di dalam cerita tersebut. Keberanian untuk membaca di depan kelas digunakan oleh beberapa guru untuk melatih siswa mereka, pengalaman ini penting bagi generasi muda, bukan hanya sekedar untuk diingat, tetapi juga sebagai cara bagi anak-anak untuk berkenalan dengan nilai-nilai umum, sikap, dan cita-cita yang termasuk dalam karakter nasional. Pengenalan dan internalisasi nilai-nilai umum oleh anggota individu merupakan suatu kebutuhan penting bagi kehidupan sosial yang stabil dalam suatu masyarakat. Hal ini diperlukan dalam proses sosialisasi generasi muda untuk terjun dalam dimensi IPS.

Proses ini bisa dimulai dari rumah, kemudian dilanjutkan dan diperpanjang di sekolah, terutama melalui mata pelajaran IPS. Kepedulian terhadap nilainilai dan proses penilaian jelas berhubungan dengan perkembangan moral anak-anak. Nilai-nilai pendidikan berkaitan dengan nilai-nilai umum dan nilainilai pribadi. Nilai-nilai kebebasan, keadilan, kesetaraan, kejujuran, pertimbangan untuk orang lain, individualisme, martabat manusia, tanggung jawab, dan kebenaran adalah contoh nilai-nilai umum yang ada dalam konsensus. Ini tidak berarti bahwa setiap orang memiliki nilai yang sama atau mereka menafsirkan dengan cara yang sama. Tetapi ada kesepakatan umum bahwa nilai-nilai tersebut mencerminkan orientasi dasar masyarakat, nilai-nilai ini merupakan bagian dari warisan politik dan agama. Mereka tergabung dalam dokumen sejarah dan dalam sistem hukum dan peradilan, mereka tampak dalam cerita rakyat dan literatur. Orang-orang yang menjalani 
kehidupan teladan yang mencerminkan nilai-nilai umum tersebut dipuji sebagai pahlawan nasional. Jika anak-anak harus diarahkan sesuai dengan nilai-nilai umum yang dianut masyarakat, mereka harus diberi contoh perilaku yang menggambarkan nilai-nilai tersebut dalam bentuk tindakan. Artinya, anak-anak muda perlu bertemu orang dengan tipe ideal yang digambarkan melalui cara hidup mereka, nilai-nilai penghargaan masyarakat dan seperti yang tampak dalam kewarganegaraannya. Hal ini terjadi karena nilai-nilai umum diinternalisasikan oleh mayoritas warga di mana kehidupan sosial dapat berlangsung tertib.

Kita mengharapkan sesama warga untuk berperilaku dengan cara yang dapat diprediksi dan konsisten dengan premis-premis dasar yang melekat dalam nilai-nilai pada konsensus umum. Keberadaan lembaga penegak hukum penting untuk melindungi masyarakat, dari minoritas orang-orang yang tidak dapat atau tidak akan hidup sesuai dengan nilai-nilai umum yang dianut oleh mayoritas. Kita dapat menikmati tatanan sosial karena sebagian besar warga telah menginternalisasikannya sesuai dengan nilai-nilai umum yang ada. Nilainilai umum yang dapat ditampilkan melalui IPS dengan cara sebagai berikut (Aisyah, 2007):

a. Kehidupan sehari-hari di dalam kelas yang menekankan pertimbangan untuk orang lain, kebebasan dan kesetaraan, kebebasan berpikir, tanggung jawab individu atas tindakan seseorang, dan martabat individu manusia.

b. Studi tentang sejarah dan perkembangan negara menekankan cita-cita yang mengilhami dan menunjukkan bahwa diperlukan usaha untuk terusmenerus bergerak mendekati kenyataan dari sesuatu yang dicita-citakan.

c. Studi biografi individu yang hidupnya mencerminkan nilai-nilai umum bangsa.

d. Studi tentang hukum, sistem hukum dan keadilan.

e. Perayaan liburan yang memperkuat nilai-nilai dan cita-cita yang terkait dengannya.

f. Analisis yang bijaksana mengenai makna pernyataan seperti pembukaan konstitusi negara.

g. Membangun kesadaran untuk situasi yang tidak sesuai dengan nilai-nilai masyarakat. 
h. Studi-studi lintas-budaya untuk menggambarkan perbedaan nilai dari satu masyarakat dengan masyarakat yang lain.

Ketika kita bergerak dari nilai-nilai umum ke nilai-nilai pribadi, peran IPS menjadi sangat berbeda dan sampai batas tertentu terkadang kurang jelas. Nilai-nilai pribadi adalah nilai-nilai yang mempengaruhi pengambilan keputusan individu dalam kehidupan pribadi mereka sendiri. Sampai batas tertentu mereka mewakili interpretasi nilai individual secara umum, yaitu operasionalisasi dari nilai-nilai umum dalam kehidupan pribadi setiap individu. Hidup modern melibatkan pembuatan pilihan dalam jumlah yang luar biasa: bagaimana memanfaatkan waktu kita, apa karir yang kita pilih, baju apa yang akan dibeli dan dipakai, di mana kita akan tinggal, produk merek apa yang akan kita beli, hobi dan kegiatan apa yang akan kita lakukan di waktu senggang, dan bagaimana cara membelanjakan uang kita.

Dalam setiap keputusan, tidak mungkin ada pilihan benar dan salah dalam arti bahwa nilai-nilai umum dasar sedang dikompromikan oleh pilihan yang baik. Sebaliknya, keputusan ini ekspresi dari preferensi individu. Untuk mencari jawaban mana yang paling benar tergantung pada ketepatan pilihan masing-masing, karena benar dan salah dalam arti absolut bukan merupakan masalah utama dalam membuat pilihan tersebut. Hal ini sangat berkaitan dengan nilai-nilai pribadi seseorang untuk membuat semua keputusan tentang pilihan kehidupan pribadinya. Pendidikan IPS tidak bisa memperkenalkan nilai-nilai pribadi dengan cara yang sama, yang bisa dilakukan IPS adalah memperkenalkan nilai-nilai umum. Selain itu, IPS juga membantu anak-anak berpikir tentang pilihan-pilihan yang mereka buat dalam hal kerangka nilai. Hal ini sering disebut dalam literatur saat ini sebagai klarifikasi nilai-nilai atau proses "untuk menilai", proses penilaian terhadap anak-anak sebaiknya dilakukan dengan memperhatikan hal-hal sebagai berikut:

a. Mendorong anak untuk membuat banyak pilihan dan membebaskan mereka.

b. Membantu mereka menemukan alternatif ketika menghadapi pilihan.

c. Membantu anak menimbang alternatif, berpikir, merenungkan konsekuensi dari masing- masing. 
d. Mendorong anak-anak untuk mempertimbangkan tentang hadiah dan penghargaan.

e. Beri kesempatan mereka untuk menegaskan pilihan.

f. Mendorong mereka untuk bertindak, berperilaku, hidup sesuai dengan pilihan mereka.

g. Membantu mereka menyadari perilaku berulang atau pola dalam hidup mereka.

Anak-anak membutuhkan pengalaman di mana mereka dihadapkan dengan konflik nilai dan pilihan harus dibuat oleh mereka. Pilihan-pilihan ini bisa berupa "barang" atau sesuatu yang diinginkan dan tidak diinginkan. Demikian pula, pilihannya bukan antara pilihan yang ilegal, tidak etis, atau bertentangan dengan norma-norma sosial. Hampir semua subjek, topik, situasi, atau gambar dapat digunakan untuk mencari nilai-nilai, pertanyaan jenis ini disarankan untuk memperoleh respon nilai ketika berdiskusi:

a. Jika Anda mengembalikan dompet seseorang yang hilang, apakah menurut Anda pantas mendapat hadiah?

b. Apakah Anda pikir Anda ingin pekerjaan seperti itu?

c. Bagaimana Anda ingin tinggal di tempat seperti itu?

d. Jika anda memenangkan hadiah uang tunai \$100, apa yang akan Anda lakukan?

e. Bagaimana perasaan Anda ketika Anda membaca cerita dilematis itu?

Mengekspresikan preferensi nilai adalah bagian normal dalam kehidupan sehari-hari, semua orang membuat pilihan berdasarkan nilai-nilai tertentu sebanyak beberapa kali setiap hari. Latihan menilai akan membangun kesadaran tentang dimensi pilihan nilai yang kita buat. Dalam pekerjaan sehari-hari di kelas, guru dapat menggunakan banyak situasi untuk membangun semacam kesadaran nilai dan melatih anak-anak untuk berpikir lebih mendalam tentang apa yang penting bagi mereka.

4. Memiliki kemampuan berkomunikasi, bekerjasama dan berkompetisi dalam masyarakat yang majemuk, di tingkat lokal, nasional dan global.

Salah satu tujuan utama pendidikan IPS adalah untuk mengembangkan sikap dan keterampilan anak-anak yang memungkinkan mereka untuk mampu memecahkan masalah secara mandiri. Untuk itu, anak-anak perlu 
mengembangkan sikap skeptis yang sehat tentang berbagai hal dan kejadian di dunia. Pemecah masalah yang baik memiliki rasa ingin tahu tentang apa yang mereka lihat dan terjadi di sekitarnya, mereka mengembangkan sikap mempertanyakan. Hal ini mungkin bisa dikategorikan sebagai unsur penyelidikan yang membuat para orangtua memiliki syarat tertentu ketika hal itu digunakan oleh anak-anak. Orang tua akan lebih memilih anak-anak mereka untuk menerima keyakinan tertentu dan ide-ide sebagai dasar kebenaran yang tidak dipertanyakan, contohnya konsep religi.

Karena konflik ini, penting bagi guru untuk tahu bahwa penyelidikan berdasarkan prosedur pemecahan masalah ilmiah adalah hanya salah satu dari beberapa cara untuk mengetahui hal-hal yang benar. Akan tetapi, kadangkadang yang diajarkan di sekolah seolah-olah ini adalah satu-satunya cara mengetahui, dan sebagai konsekuensinya, kita mengasingkan mereka yang tidak berbagi dengan pandangan ini. Cara paling umum untuk mengetahui sesuatu adalah dengan mengandalkan sumber otoritatif, guru pertama dan terbaik adalah orang tua kita. Sebagai anak-anak muda, kita menganggap orang tua sebagai sumber otoritatif pengetahuan, mereka menjaga dan melindungi kita. Mereka menjawab pertanyaan-pertanyaan kita tentang bagaimana sesuatu bekerja. Karena mereka tampaknya tahu begitu banyak hal dan apa yang mereka beritahukan biasanya benar, kita belajar untuk menerima bahwa penjelasan mereka memang benar. Saat kita beranjak dewasa, kita bergantung pada otoritas lain, guru, ilmuwan, buku, dokter, sejarawan, dan seterusnya. Kita tidak punya waktu untuk menemukan kembali segala sesuatu untuk diri kita sendiri, dan bahkan jika kita melakukannya, ini akan menjadikan waktu kita sangat tidak efisien. Sebenarnya kita bisa melakukannya, walaupun banyak yang kita ketahui tentang fenomena sosial dan alam, tetapi kita tidak memiliki cara lain untuk mendapatkan informasi tersebut.

Permasalahan yang dihadapi ketika menggunakan otoritas sebagai cara untuk mengetahui sesuatu hal adalah kredibilitas otoritas tersebut. Kita harus cukup tahu tentang obat, misalnya untuk dapat membedakan antara kebijaksanaan seorang dokter yang kompeten dan yang satu kurang mampu. Cepat atau lambat kita semua mengetahui bahwa orang tua kita bukan 
merupakan sumber informasi yang terpercaya pada semua mata pelajaran. Kita juga belajar bahwa tidak semua yang kita baca dalam buku dapat diterima sebagai sesuatu yang benar. Kita perlu mengetahui pesan yang akan disampaikan penulis sebelum kita dapat mengevaluasi validitasnya. Harus jelas bahwa potensi konflik antara penyelidikan sebagai cara untuk mengetahui dan penggunaan kekuasaan cukup besar. Orang tua khawatir jika sekolah merusak persepsi anak bahwa mereka merupakan sumber informasi otoritatif. Konflik menjadi lebih besar jika orang tua menganggap pengajaran di sekolah membahayakan keyakinan anak mengenai Tuhan sebagai otoritas tertinggi. Pengetahuan pribadi termasuk cara lain untuk mengetahui, kita tahu sesuatu yang benar hanya karena kita percaya hal itu terjadi. Hal tersebut menandakan bahwa pengalaman adalah contoh pengetahuan pribadi yang dianggap benar oleh seseorang yang memiliki pengalaman tersebut. Cara lain adalah dengan memecahkan masalah secara ilmiah, bila prosedur ini digunakan, biasanya disajikan dengan lima langkah berikut: (1) identifikasi masalah, (2) pembentukan hipotesis, (3) pengumpulan data, (4) pengujian hipotesis dalam hal bukti (atau data), dan (5) menarik kesimpulan berdasarkan bukti. Proses ini tidak harus dikonseptualisasikan sebagai serangkaian langkah, melainkan sebagai cara berpikir yang memerlukan bukti kuat.

Kesimpulan yang diterima sementara didasarkan pada pemecahan masalah ilmiah, berdasarkan informasi yang tersedia pada saat itu. Langkah ini menjadi awal untuk penyempurnaan lebih lanjut dari penjelasan dan kesimpulan, atau bahkan penjelasan dan kesimpulan yang berbeda pada waktu selanjutnya, ketika informasi lebih lanjut sudah tersedia. Prosedur-prosedur ini menekankan probabilitas sesuatu yang benar dalam hal bukti, bukannya benar dalam pengertian absolute, ini berarti bahwa tidak ada daerah tertutup untuk penyelidikan lebih lanjut. Proses berpikir terdiri dari serangkaian sub keterampilan, dan dapat diidentifikasi sebagai berikut (Harianti, 2000):

a. Mengidentifikasi masalah dan pertanyaan untuk studi.

b. Membuat kesimpulan dan menarik kesimpulan dari data.

c. Membuat perbandingan.

d. Mengembangkan hipotesis.

e. Menggunakan bukti untuk menguji hipotesis. 
f. Perencanaan bagaimana belajar pertanyaan atau masalah.

g. Mendapatkan data dari berbagai sumber.

h. Memprediksi hasil yang mungkin.

i. Memutuskan apa bukti yang diperlukan dalam mempelajari masalah.

j. Memutuskan apa bukti yang relevan dengan penelitian ini.

Keterampilan ini harus dimasukkan dalam pekerjaan yang sedang berlangsung di kelas jika peserta didik ingin mengembangkan kemampuannya. Tentu saja, tidak semua sub keterampilan ini muncul dalam pelajaran IPS setiap hari. Dalam pembelajaran dengan metode penyelidikan, buku pelajaran adalah data atau sumber informasi, dan harus digunakan bersama dengan sumber-sumber informasi lainnya. Tidak semua cara mengajar IPS perlu, atau bahkan harus berorientasi pada penyelidikan. Modus mengajar yang dipilih harus konsisten dengan tujuan yang ingin dicapai. Jika tujuannya adalah untuk menyampaikan informasi kepada anak-anak atau untuk mengajarkan keterampilan, cara mengajar eksposisi dan demonstrasi lebih efektif dan efisien daripada penyelidikan. Akan tetapi, jika tujuannya adalah untuk melatih kemampuan berpikir dan keterampilan menyelesaikan masalah, strategi penyelidikan harus digunakan.

\section{Penutup}

Tujuan utama Ilmu Pengetahuan Sosial ialah untuk mengembangkan potensi peserta didik agar peka terhadap masalah sosial yang terjadi di masyarakat, memiliki sikap mental positif terhadap perbaikan segala ketimpangan yang terjadi, dan terampil mengatasi setiap masalah yang terjadi sehari-hari baik yang menimpa dirinya sendiri maupun yang menimpa masyarakat. Tujuan tersebut dapat dicapai manakala program-program pembelajaran IPS di sekolah memenuhi kriteria-kriteria sebagai berikut: 1) Memiliki kesadaran dan kepedulian terhadap masyarakat atau lingkungannya, melalui pemahaman terhadap nilai-nilai sejarah dan kebudayaan masyarakat; 2) Mengetahui dan memahami konsep dasar dan mampu menggunakan metode yang diadaptasi dari ilmu-ilmu sosial yang kemudian dapat digunakan untuk memecahkan masalah-masalah sosial; 3) Mampu menggunakan model-model dan proses berpikir serta membuat keputusan untuk menyelesaikan isu dan masalah yang berkembang di masyarakat; 4) Menaruh perhatian terhadap isu-isu dan masalah- 
masalah sosial, serta mampu membuat analisis yang kritis, selanjutnya mampu mengambil tindakan yang tepat; 5) Mampu mengembangkan berbagai potensi sehingga mampu membangun diri sendiri agar survive yang kemudian bertanggung jawab membangun masyarakat.

\section{Daftar Pustaka}

Aisyah, S. (2007). Pembelajaran Terpadu. Jakarta: Universitas Terbuka.

Depdiknas. (2006). Peraturan Menteri Pendidikan Nasional No. 22 Tahun 2006 Tentang Standart Isi.

Fraenkel, Jack R. (1980). Helping Students Think Value Strategies For Teaching Social Studies. New Jersey: Prentice Hall.

Harianti, D. (2000). Model Pembelajaran Terpadu IPS. Jakarta: Depdiknas.

Hidayati, M. (2008). Pengembangan Pendidikan Ilmu Pengetahuan Sosial Sekolah Dasar. Jakarta: Direktorat Jederal Pendidikan Tinggi Departemen Pendidikan Nasional

Indrawati. (2009). Model Pembelajaran IPS Terpadu di SD. Jakarta: Pusat Pengembangan dan Pemberdayaan Pendidikan dan Tenaga Kependidikan (PPPPTK).

Martorella, P.H. (1994). Social Studies For Elementary School Children. Developing Young Citizen. New York: Merill.

Pusat Kurikulum. (2006). Model Pengembangan Silabus Mata Pelajaran dan RPP IPS Terpadu. Jakarta.

Sapriya. (2009). Pendidikan IPS: Konsep dan Pembelajaran. Bandung: Rosda Karya.

Somantri. (2001). Menggagas Pembaharuan Pendidikan IPS. Bandung: Remaja Rosdakarya. 